\title{
Proximate Composition and Thermal Properties of Fabricated Fresh Beef during Freezing
}

\author{
Okoronkwo, N. C.*, Eze, J. I., Ene, I. N. \\ Department of Food Science and Technology, University of Nigeria Nsukka, Nigeria
}

Copyright $\bigcirc 2017$ by authors, all rights reserved. Authors agree that this article remains permanently open access under the terms of the Creative Commons Attribution License 4.0 International License

\begin{abstract}
This study presented the effects of temperature and shape on the thermal properties of beef. Round cut of beef was fabricated into irregular, triangular, circular, and rectangular shapes which were subjected to different freezing temperatures of $-13,-17$, and $-30^{\circ} \mathrm{C}$. Specific heat, total heat transfer, density and proximate composition of each meat sample were determined after freezing. Total heat transfer among the shapes varied significantly $(p<0.05)$, circular and rectangular shapes had the highest value of $0.460 \mathrm{KJ}$ while triangular shapes had the least value of 0.431 KJ. Density and specific heat decreased significantly $(p<0.05)$, with decrease in temperature, but total heat transfer increased significantly $(\mathrm{p}<0.05)$ with increase in temperature from -13 to $-30^{\circ} \mathrm{C}$. It was observed that different fabricated beef shapes significantly $(\mathrm{p}<0.05)$ affected total heat transfer during freezing. Also, thermal properties of beef at freezing were found to be dependent on the freezing temperatures. Circular shaped meat samples had the best thermal property behaviour at $-30^{\circ} \mathrm{C}$. From the results of the study, it is evident that thermal properties of beef perform better at lower freezing temperatures.
\end{abstract}

Keywords Thermal Properties, Density, Total Heat Transfer, Specific Heat, Freezing Temperatures, Beef

\section{Introduction}

Beef is the culinary name for meat from bovines, especially cattle. It can be harvested from bulls, heifers or steers and its acceptability as food source varies in different parts of the world [1]. Following exsanguination, the process of converting muscle to meat begins and it becomes subject to degradation by chemical, physical, enzymic and microbial reactions. Preservation methods are designed to prevent this deterioration from taking place and are absolutely essential for extending the shelf-life during storage of meat and meat products. Methods of preserving beef include refrigeration, freezing, thermal processing, and dehydration, among others. Effective means of preservation is a fundamental requirement of any modern meat distribution, marketing and storage system. The development of efficient methods of preservation has therefore engaged the attention of scientists in Nigeria in recent times [2].

Thermal properties of food must be known to perform the various heat calculations involved in designing storage and refrigeration equipment and estimating process times for refrigerating, freezing, heating, or drying of foods. Thermal properties change dramatically during freezing and must be considered [3]. Food thermal properties can be defined as those properties controlling the transfer of heat in a specified food [3]. Heat transfer involves the transfer of heat into or out of a food. There are three ways that heat can be transferred: by conduction, radiation and convection [3]. Knowledge of the thermal properties of food is required in order to evaluate the heat transfer in food products [4].

The objectives of this study are:

I. To freeze different shapes of beef at different freezing temperatures.

II. To measure density, total heat transfer and specific heat of beef at different freezing temperatures.

III. To determine the effects of shapes and temperature on thermal properties of beef during freezing.

\section{Materials and Methods}

1. Sample collection: Fresh round cut of beef for this study was purchased from Ogige main market, Nsukka, Enugu state. The extra- lean fresh beef sample was fabricated into different shapes of equal mass (10 g). The shapes were: irregular, triangular, rectangular and circular shapes. The cut and weighed beef samples were frozen at temperatures -13 , -17 and $-30{ }^{\circ} \mathrm{C}$. Specific heat, total heat transfer and density of the samples at each temperature were measured.

2. Density: The density of each piece of meat at the different low temperatures was measured using direct measurement of mass and volume by [5]. Each piece of meat was weighed to obtain the mass, and volume was determined. Density was thus calculated by dividing the mass of each piece of meat by its volume. 
3. Specific heat: Specific heat was determined using Siebel's equation [6]:

Specific heat of frozen food $(\mathrm{Cp})=1.26 \mathrm{a}+0.84(\mathrm{KJ} /$ Kg. $\left.{ }^{\circ} \mathrm{C}\right)$

Where $\mathrm{a}=$ moisture content of the food, and the constant $0.84 \mathrm{KJ} / \mathrm{Kg}{ }^{\circ} \mathrm{C}$ represents the specific heat of the solid (non-water) portion of the food.

4. Total heat transfer: Total heat transfer $(\mathrm{KJ})$ was determined using the equation [6]:

$$
\mathrm{Q}=\mathrm{mc} \theta
$$

Where, $\mathrm{Q}=$ total heat transferred $(\mathrm{KJ})$ from the sample, $\mathrm{m}$ $=$ mass, $\mathrm{C}=$ specific heat, $\theta=$ change in temperature of the food samples.

5. Proximate analysis: Moisture content, crude protein, crude fat and ash content of each sample was determined according to the standards of [7].

6. Experimental design and statistical analysis: The experimental design that was used is split-plot in completely randomised design. Data generated from the study was subjected to analysis of variance using the Statistical Package for Social Sciences (SPSS, version 20.0). Significant means were separated using Duncan's new multiple range test at $5 \%$ level of significance.

\section{Results and Discussion}

\subsection{Thermal Properties of Meat Samples}

The effect of different shapes on specific heat, density and total heat transfer of the meat samples during freezing is shown in Table 1.

\subsubsection{Total Heat Transfer}

Significant $(\mathrm{p}<0.05)$ differences were observed among the treatments in values for total heat transfer. Circular and rectangular meat samples had higher total heat transfer values $(0.460 \mathrm{KJ})$ than those of triangular and irregular shapes ( $0.431 \mathrm{KJ}$ and $0.446 \mathrm{KJ}$ respectively). Meat samples of circular and rectangular shapes exhibited statistically non-significant differences $(p>0.05)$. Triangular meat samples recorded least values for total heat transfer; this is because heat transfer depends on shape of food, surface roughness, type of cooling fluid and the velocity of fluid [6].

\subsubsection{Density and Specific Heat Capacity}

No significant $(p>0.05)$ differences were observed in values for density and specific heat capacity among the treatments. Density values for the meat shapes ranged from 0.121 to $0.185 \mathrm{Kg} / \mathrm{m}^{3}$ while values for specific heat capacity ranged from 1.720 to $1.729 \mathrm{KJ} / \mathrm{Kg}{ }^{\circ} \mathrm{C}$.

\subsection{Effect of Temperature on Thermal Properties of Meat Samples}

Table 2 shows the effect of different temperatures on the thermal properties of meat samples during freezing. It is evident from the table that density, specific heat capacity and total heat transfer were found to be highly significant ( $\mathrm{p}<$ 0.05 ) among the samples.

\subsubsection{Density}

Meat samples at the temperature of $-13^{\circ} \mathrm{C}$ recorded the highest density value $\left(0.250 \mathrm{~kg} / \mathrm{m}^{3}\right)$ among the treatments, while samples at $-30^{\circ} \mathrm{C}$ recorded the least value of 0.088 $\mathrm{kg} / \mathrm{m}^{3}$. It was observed that density values decreased with temperature decrease this is because water expands by $10 \%$ on freezing and thus with increasing amount of ice formed below the initial freezing point, the food tends to expand (density decreases) as temperature decrease [8].

Table 1. Effect of shapes on thermal properties of meat samples

\begin{tabular}{|c|c|c|c|c|}
\hline Parameters & Irregular & Triangle & Circle & Rectangle \\
\hline Density $\left(\mathrm{Kg} / \mathrm{m}^{3}\right)$ & $0.125 \pm 0.022$ & $0.121 \pm 0.030$ & $0.149 \pm 0.022$ & $0.185 \pm 0.005$ \\
\hline Specific heat capacity $\left(\mathrm{KJ} / \mathrm{kg}^{\circ} \mathrm{C}\right)$ & $1.728 \pm 0.017$ & $1.720 \pm 0.021$ & $1.729 \pm 0.018$ & $1.721 \pm 0.033$ \\
\hline Total heat transfer $(\mathrm{KJ})$ & $0.446^{\mathrm{ab}} \pm 0.008$ & $0.431^{\mathrm{b}} \pm 0.010$ & $0.460^{\mathrm{a}} \pm 0.008$ & $0.460^{\mathrm{a}} \pm 0.005$ \\
\hline
\end{tabular}

Means values in the rows with different superscript letters are significantly $(\mathrm{p}<0.05)$ different.

Table 2. Effect of temperature on the thermal properties of meat samples

\begin{tabular}{|c|c|c|c|}
\hline Parameters & $-13^{\circ} \mathrm{C}$ & $-17^{\circ} \mathrm{C}$ & $-30^{\circ} \mathrm{C}$ \\
\hline Density $\left(\mathrm{Kg} / \mathrm{m}^{3}\right)$ & $0.250^{\mathrm{a}} \pm 0.019$ & $0.097^{\mathrm{b}} \pm 0.030$ & $0.088^{\mathrm{b}} \pm 0.020$ \\
\hline Specific heat capacity $\left(\mathrm{KJ} / \mathrm{kg}^{\circ} \mathrm{C}\right)$ & $1.748^{\mathrm{a}} \pm 0.015$ & $1.738^{\mathrm{a}} \pm 0.022$ & $1.688^{\mathrm{b}} \pm 0.035$ \\
\hline Total heat transfer $(\mathrm{KJ})$ & $0.427^{\mathrm{b}} \pm 0.007$ & $0.439^{\mathrm{b}} \pm 0.010$ & $0.492^{\mathrm{a}} \pm 0.0 .011$ \\
\hline
\end{tabular}

Means values in the rows with different superscript letters are significantly $(\mathrm{p}<0.05)$ different. 


\subsubsection{Specific Heat Capacity}

There was a significant $(p<0.05)$ difference in values for specific heat capacity among the samples at different freezing temperatures. Specific heat capacity of meat samples at the different temperatures ranged from 1.668 to $1.748 \mathrm{KJ} / \mathrm{Kg}{ }^{\circ} \mathrm{C}$. Samples at $-30^{\circ} \mathrm{C}$ had the least value of $1.668 \mathrm{KJ} / \mathrm{Kg}{ }^{\circ} \mathrm{C}$ while $-13^{\circ} \mathrm{C}$ had the highest value of 1.748 $\mathrm{KJ} / \mathrm{Kg}{ }^{\circ} \mathrm{C}$. It was observed that specific heat capacity decreased as temperature decreased.

\subsubsection{Total Heat Transfer}

Values for total heat transfer at $-13{ }^{\circ} \mathrm{C}$ and $-17{ }^{\circ} \mathrm{C}$ were not significantly $(\mathrm{p}>0.05)$ different, although, samples at $-17^{\circ} \mathrm{C}$ had higher numerical value. Meat samples at $-30{ }^{\circ} \mathrm{C}$ had highest value of $0.492 \mathrm{KJ}$ for total heat transfer among the treatments. It was observed that total heat transfer values increased with temperature decrease. The rate of heat transfer depends upon the differences in temperature between the bodies, the greater the difference in temperature, the greater the rate of heat transfer [9].

\subsection{Proximate Composition of Meat Samples}

The proximate composition of the meat samples at different temperatures is shown in Table 3 . The proximate composition determined is based on the effect of temperature on each composition.

Table 3. Proximate composition of meat samples at different temperatures

\begin{tabular}{|c|c|c|c|}
\hline Parameters & $-13^{\circ} \mathrm{C}$ & $-17^{\circ} \mathrm{C}$ & $-30^{\circ} \mathrm{C}$ \\
\hline $\begin{array}{c}\text { Crude } \\
\text { protein (\%) }\end{array}$ & $18.51 \pm 1.074$ & $18.35 \pm 0.314$ & $18.45 \pm 0.906$ \\
\hline $\begin{array}{c}\text { Crude fat } \\
(\%)\end{array}$ & $3.15 \pm 1.247$ & $2.70 \pm 0.717$ & $2.83 \pm 1.270$ \\
\hline $\begin{array}{c}\text { Moisture } \\
\text { content (\%) }\end{array}$ & $69.33^{\mathrm{b}} \pm 1.060$ & $70.86^{\mathrm{ab}} \pm 1.482$ & $71.79^{\mathrm{a}} \pm 1.003$ \\
\hline Ash (\%) & $1.11 \pm 0.112$ & $1.13 \pm 0.052$ & $1.08 \pm 0.070$ \\
\hline
\end{tabular}

Means values in the rows with different superscript letters are significantly $(\mathrm{p}<0.05)$ different.

From the Table, there was no significant $(p>0.05)$ difference in the values for crude protein, crude fat and ash content among the meat samples at different freezing temperatures. Values for crude protein content in the samples ranged from 18.35 at $-17^{\circ} \mathrm{C}$ to $18.51 \%$ at $-13^{\circ} \mathrm{C}$, crude fat content ranged from 2.70 to $3.15 \%$ and ash content ranged from 1.08 to $1.13 \%$. There was a significant $(\mathrm{p}<0.05)$ difference in values of moisture content for meat samples heated with 13 and $30^{\circ} \mathrm{C}$. It was observed that moisture content increased with temperature decrease, which can be attributed to less drip loss at higher freezing rate. Drip loss is reduced as temperature decreases, which minimizes the evaporation rate, which is the rate at which water moves from the product into the air [10]. Meat samples at $-30^{\circ} \mathrm{C}$ had the highest moisture content $(71.79 \%)$ although it is not significantly $(p>0.05)$ different from values $(70.86 \%)$ for meat samples at $-17^{\circ} \mathrm{C}$. Samples at $-13^{\circ} \mathrm{C}$ had the lowest moisture content value of $69.33 \%$.

\section{Conclusions}

To ensure good meat quality during low temperature storage, temperature of storage and fabrication of meat should always be considered. From the results of the study, it is evident that shapes of beef do not affect its density and specific heat but there is an obvious dependency of total heat transfer on the shapes of meat. Thermal properties have a great dependence on temperature as density and specific heat decrease with temperature decrease while total heat transfer increases with increase in temperature difference. This study also shows that circular shaped meat samples have the best heat transfer rate while thermal properties performed better at lower freezing temperatures. Temperature has no effect on proximate composition of beef except for moisture content that increases with temperature decrease. There was no significant ( $p>0.05$ ) difference in the proximate composition of meat samples except for moisture content that increased at decreased temperature.

\section{REFERENCES}

[1] Anon. (2016). Beef. www.scholar.google.com.Assessed on $20^{\text {th }}$ February, 2016.

[2] Ikeme, A. I. (1990). Meat Science. Africana-Fep Publishers Limited, Onitsha, Nigeria. pp. $119-124$.

[3] Lozano, J. E. (2002). Thermal Properties of Food. Journal of Food Engineering, 1: 200 - 259.

[4] Andreasen, M. B. (2009). Modelling of heat and mass transfer in food processing. Www.comsol.com Assessed on $8^{\text {th }}$ July, 2016.

[5] Callaghan, R. (2016). Ways to determine density. www.classroom.synoym.com Assessed on $20^{\text {th }}$ February, 2016.

[6] Cengel, Y. A. (2007). Refrigeration and freezing of foods. In: Heat and Mass Transfer: A Practical Approach. McGraw-Hill Education Publishers, United States. pp. 560 - 590.

[7] AOAC (2010). Official method of analysis, $18^{\text {th }}$ Edition. Association of Official Analytical Chemist. Gaithersburg, Maryland, USA.

[8] Evans, J. A. (20s08). Frozen Food Science and Technology. Blackwell Publishing Limited, Oxford, England. pp. 10 - 25.

[9] Earle, R. L. (1966). Unit Operations in Food Processing. Pergamon Press Limited, London. pp. 69 - 136.

[10] United Nations Industrial Development Organization (UNIDO) (1992), Freezing Methods and Quality Loss at Freezing Temperatures. www.unido.org Assessed on $12^{\text {th }}$ February, 2016. 